\title{
Pengaruh persentase campuran kulit kayu gelam (Melaleuca Cajuputi) dan cangkang karet (Hevea Brasiliensi) terhadap karakteristik pembakaran briket
}

\author{
Misbachudin ${ }^{1}$, Raybian Nur ${ }^{2}$ \\ 1,2Program Studi D3Teknik Otomotif Politeknik Hasnur \\ JI. Brigjen Hasan Basri, Barito Kuala 70582, Kalimantan Selatan-Indonesia \\ Email: m1584ch.mt@gmail.com
}

\begin{abstract}
Development of alternative energy sources that can be one of the potential to produce energy in overcoming the fuel energy crisis. The availability of a lot of rubber trees and gelam bark waste in the area of South Kalimantan so it needs to be used to be processed as raw material for briquettes. In this research using a mixture of rubber shell briquettes and gelam bark waste by varying the weight percentage of the mixture. Tests carried out by burning the briquette on a heating element, to determine the characteristics of combustion in briquettes which include the time of initial ignition, the length of the combustion process, and the change in mass of the briquette to ashes. The results show the length of time of starting the ignition and the length of time the combustion process has decreased with an increasing percentage of gelam bark mixture that is during $13.7 \mathrm{~s}$ with a burning time of 5.54 minutes. This is due to fibrous and brittle gelam wood bark so it is flammable and contains volatile matter. High lignin content in the rubber shell leaves more ash than gelam bark which is equal to $5.75 \mathrm{gr}$
\end{abstract}

Keywords : Rubber shell, gelam bark, briquettes, alternative energy, combustion characteristics.

\begin{abstract}
Abstrak
Pengembangan sumber energi alternatif yang dapat menjadi salah satu potensi menghasilkan energi dalam mengatasi krisis energi bahan bakar. Dengan melihat banyaknya buah karet dan limbah kulit gelam di daerah Kalimantan Selatan sehingga perlu dimanfaatkan untuk diolah sebagai bahan baku briket. Pada penelitian ini menggunakan briket campuran cangkang karet dan limbah kulit gelam dengan memvariasikan persentase berat campuran bahan. Pengujian dilakukan dengan membakar briket di atas sebuah elemen pemanas, untuk mengetahui karakteristik pembakaran pada briket yang meliputi waktu penyalaan awal, lama proses pembakaran, dan perubahan massa briket hingga menjadi abu. Hasil pengujian menunjukkan, lama waktu mulai penyalaan dan lama waktu proses pembakaran mengalami penurunan seiring bertambahnya persentase campuran kulit kayu gelam yaitu selama 13,7 s dengan lama pembakaran selama 5,54 menit. Hal ini disebabkan kulit kayu gelam berserat dan rapuh sehingga mudah terbakar dan kandungan volatile matternya. Kandungan lignin yang tinggi pada cangkang karet menyisakan abu yang lebih banyak dibandingkan kulit kayu gelam yaitu sebesar 5,75 gr.
\end{abstract}

Kata kunci: Cangkang karet, kulit gelam, briket, energi alternatif, karakteristik pembakaran.

\section{Pendahuluan}

Kebutuhan akan bahan bakar fosil seperti minyak bumi, gas alam dan batu bara yang selama ini merupakan sumber energi utama setiap hari semakin meningkat, sedangkan cadangan sumber energi semakin menipis dan dapat mengakibatkan krisis energi. Solusi untuk 
mengurangi penggunaan bahan bakar fosil, yaitu dengan menggunakan energi terbarukan seperti tenaga surya, tenaga angin, tenaga air, panas bumi dan biomassa selain menggunakan energi terbarukan juga dapat menggunakan energi alternatif lainnya seperti briket.

Briket yang paling umum digunakan adalah briket batu bara, briket arang, briket gambut, dan biobriket. Biobriket bisa diproduksi secara berkelanjutan dengan ketersedian bahannya, merupakan sumber energi alternatif yang dapat digunakan pada proses pembakaran.Salah satu pemanfaatkan biomassa dalam penelitian ini adalah cangkang karet dan limbah kulit kayu gelam. Tanaman karet (havea brasiliensis) memiliki peranan utama dalam penghasil getah yang dimiliki oleh pemerintah,swasta dan rakyat.Pada tahun 2013 tercatat bahwa dengan luas area tersebut Kalsel mampu menghasilkan produksi karet sebesar $172.372 \mathrm{~kg}$ karet kering (KK). Dengan kata lain produktivitas area perkebunan karet di Kalsel mencapai 926,35 kg KK/ha [1].

Sedangkan kayu gelam atau Melaleuca cajuputi merupakan spesies yang tumbuh alami di hutan rawa, yang sering dimanfaatkan untuk kontruksi perumahan, dikarenakan kayunya sangat kuat (kelas kuat II dan kelas awet III). Di Kalimantan Selatan pemerintah telah mengembangkan hutan rakyat dengan luasan mencapai 2.895 ha, dan yang paling luas berada di kabupaten Tanah Laut yakni seluas 935 ha.Galam (Melaleuca cajuputi) merupakan tumbuhan yang bisa mencapai tinggi $40 \mathrm{~m}$ dan diameter setinggi dada sekitar $35 \mathrm{~cm}$. Tumbuhan ini tumbuh di rawa air tawar dan di daratan tergenang musiman di tepi laut. Batang galam banyak digunakan untuk bahan pokok atau penunjang konstruksi, bahan baku industri penggergajian, dan kayu bakar.

Penelitian mengenai briket telah banyak dilakukan oleh peneliti, masingmasing mempunyai karakteristik dan tujuan yang berbeda. Berikut beberapa penelitian briket yang telah dilakukan dan digunakan sebagai dasar untuk mendukung pelaksanaan penelitian ini.

Cara pembuatan biobriket kulit dari dan bungkil biji karet dengan perekat tetes tebu sebagai bahan bakar alternatif, untuk mengetahui perbandingan ideal biobriket dengan dilakukan pengujian meliputi nilai kalor, kadar abu, kadar air, kerapatan dan tekanan dari biobriket dengan perbandingan bahan dasar kulit dan bungkil biji karet, menggunakan model biobriket silinder lingkaran dengan diameter $4,3 \mathrm{~cm}$ dan tinggi $5 \mathrm{~cm}$, massa total biobriket sebesar $50 \mathrm{gr}$, menggunakan perekat tetes tebu sebanyak $20 \%$ dari massa total biobriket, hasil pengujian untuk kadar abu tertinggi pada bungkil biji karet dengan selisih antara kadar abu terendah dan tertinggi sebesar 3,05\% dibandingkan dengan kulit biji karet [2].

Karakteristik pembakaran biobriket kulit dan cangkang karet dengan perekat glyserin. Dari penelitian ini diketahui Penggunaan campuran pada cangkang karet api cenderung stabil, karena memiliki kadar volatile matter rendah. Penambahan campuran perekat glyserin 9 $\%$ pada biobriket kulit dan cangkang karet tidak mudah rapuh dengan penggunaan perekat meningkatkan kadar abu pada biobriket kulit dan cangkang karet. Laju pembakaran setiap variasi biobriket kulit dan cangkang karet dengan penyalaan awal yang lebih cepat terjadinya api pada variasi campuran kulit $64 \%$ dan cangkang $27 \%$ dengan waktu rata- rata 16,7 detik [3].

Penelitian lain pengaruh prosentase briket campuran limbah serbuk kayu gergajan dan limbah daun kayu putih terhadap nilai kalor dan kecepatan pembakaran. Dalam penelitian ini briket terbuat dari campuran serbuk kayu gergajan dan limbah daun kayu putih dengan perekat tepung sagu, dan persentase campuran 100\%:0\%, 80\%:20\%, 60\%:40\%, 40\%:60\%, 20\%:80\%, 0\%:100\%, Briket berbentuk silinder pejal 
dengan ukuran partikel 20 mesh $(0,841$ $\mathrm{mm})$ dan $>20$ mesh $(0,841 \mathrm{~mm})$ serta diberi tekanan $30 \mathrm{MPa}$. Dari penelitian ini diketahui ukuran partikel dan persentase campuran memiliki pengaruh terhadap nilai kalor, sisa pembakaran, dan temperatur briket [4].

Kemudian pemanfaatan limbah kayu galam dan limbah tempurung kelapa menjadi bahan baku pembuatan briket arang. Dari penelitian tsb diperoleh pengujian sifat fisika dan kimia briket arang dari limbah kayu galam dan limbah tempurung kelapa menunjukkan bahwa pada komposisi $100 \%$ galam, $100 \%$ tempurung kelapa, 50\% galam : $50 \%$ tempurung kelapa, $75 \%$ galam : $25 \%$ tempurung kelapa dan 25\% galam : $75 \%$ tempurung kelapa nilai kerapatan briket arang dari limbah kayu galam dan limbah tempurung kelapa berkisar antara 0.6512 $\mathrm{gr} / \mathrm{cm} 3$ - $0.8578 \mathrm{gr} / \mathrm{cm} 3$, nilai kadar air berkisar antara 3,4562- 7,5276\%, nilai zat mudah menguap berkisar antara $26,8976 \%$ - 36,1357\%, nilai kadar abu berkisar antara $19,2822 \%$ - $29.9671 \%$, nilai kadar karbon terikat berkisar antara $33.8972 \%$ $51.0183 \%$ dan nilai kalor berkisar antara $4.418 \mathrm{kal} / \mathrm{gr}-5.965 \mathrm{kal} / \mathrm{gr}$ [5].

Penelitian ini dilakukan untuk mengetahui pengaruh Persentase Campuran Cangkang Karet (Hevea Brasiliensi) dan Kulit Kayu Gelam (Melaleuca Cajuputi) Terhadap Karakteristik Pembakaran Briket. Sedangkan karakteristik pembakarannya meliputi: penyalaan awal briket, lama pembakaran briket, dan massa akhir briket selama proses pembakaran.

\section{Tinjauan Pustaka}

Pembakaran adalah reaksi kimia antara bahan bakar dan pengoksidasi (udara atau oksigen) dengan bahan yang dapat terbakar, disertai timbulnya cahaya dan menghasilkan kalor. Dalam proses pembakaran terdapat beberapa fenomena antara lain adalah interaksi pada proses proses kimia dan fisika, pelepasan panas dari energi ikatan-ikatan kimia, proses perpindahan panas dan massa, dan fenomena gerakan-gerakan dari fluida yang ada di dalamnya.

Proses pembakaran terjadi ketika dalam suatu lingkungan terdapat bahan bakar dan oksidator yang dikenai energi aktivasi, besarnya energi aktivasi bergantung pada jenis bahan bakar yang digunakan energi aktivasi dapat berupa panas maupun cahaya. Energi aktivasi ini akan mengaktifkan molekul-molekul bahan bakar sehingga molekul tersebut menjadi bermuatan. Kandungan utama bahan bakar adalah karbon (C) dan hydrogen $(\mathrm{H})$, sedangkan untuk kandungan minoritas bahan bakar adalah nitrogen $(\mathrm{N})$, sulfur (S), oksigen (O), korbondioksida (CO2), dan air (H2O)

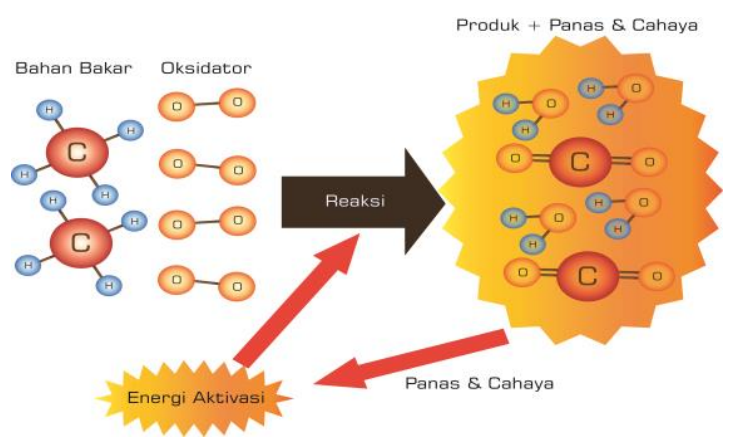

Gambar 1. Skematik proses pembakaran

Bahan bakar padat banyak digunakan pada proses pembakaran pembangkitan uap untuk pembangkit daya, prosesing, dan sebagainya. Beberapa contoh bahan bakar padat antara lain: kayu bakar, arang, batubara, mesiu, dan sebagainya. Pada proses pembakaran bahan bakar padat terlebih dahulu mencair, kemudian menguap menjadi gas dan lalu terbakar [6].

\section{Metode penelitian}

Metode penelitian yang digunakan dalam penelitian ini adalah metode eksperimental (experimental method). Jenis penelitian ini digunakan untuk menguji karakteristik pembakaran briket campuran cangkang karet dan kulit gelam. Hasil percobaan eksperimental akan dimasukkan ke dalam sebuah tabel penelitian, kemudian dianalisis dan dibuat 
menjadi sebuah diagram untuk melihat kecenderungan yang terjadi.

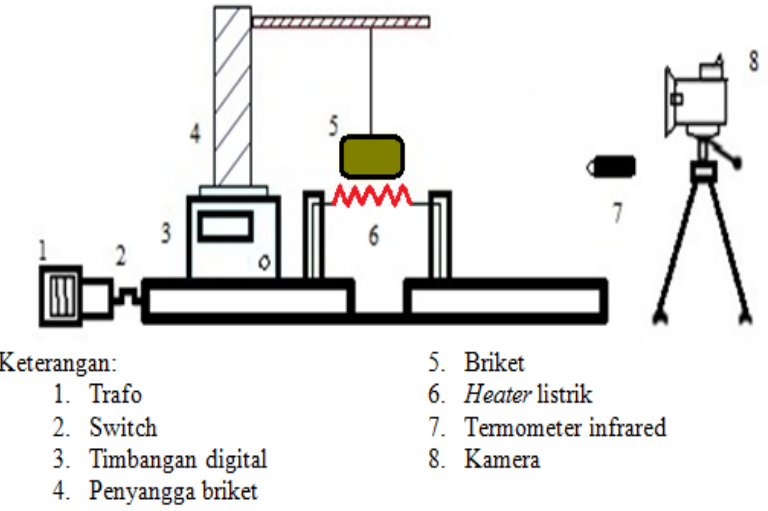

Gambar 2. Skema instalasi penelitian

Dalam penelitian ini yaitu persentase campuran cangkang karet dan kulit gelam, yaitu 100\%:0\%, 30\%:70\%, 50\%:50\%, 70\%:30\%, dan 0\%:100\%, dalam persentase berat. Ukuran partikel briket, yaitu partikel yang lolos ayakan 60 mesh $(0,250 \mathrm{~mm})$; perekat yang digunakan berupa kanji dengan persentase penambahan sebesar 1 gram untuk setiap variasi campuran briket; pada proses pembriketan, untuk setiap variasi briket ditekan selama 10 detik; tekanan pembriketan $10 \mathrm{~kg} / \mathrm{cm}^{2}$. Data yang diambil berupa karakteristik pembakaran briket yang terdiri dari;Penyalaan awal briket (detik); lama proses pembakaran (menit) dan massa akhir (gr).

\section{Hasil dan Pembahasan}

Hasil dari pengambilan data bertujuan untuk mengetahui karakteristik pembakaran briket yaitu waktu penyalaan awal, lama waktu proses pembakaran, perubahan massa biobriket pada waktu proses pembakaran hingga menjadi abu, Berikut merupakan hasil pengambilan data yang telah dilakukan.

1. Waktu mulai menyala pada proses pembakaran briket

Pada proses pembakaran briket dari variasi campuran kulit kayu gelam dan cangkang karet waktu yang diperlukan untuk terjadinya api selama proses pembakaran berlangsung.

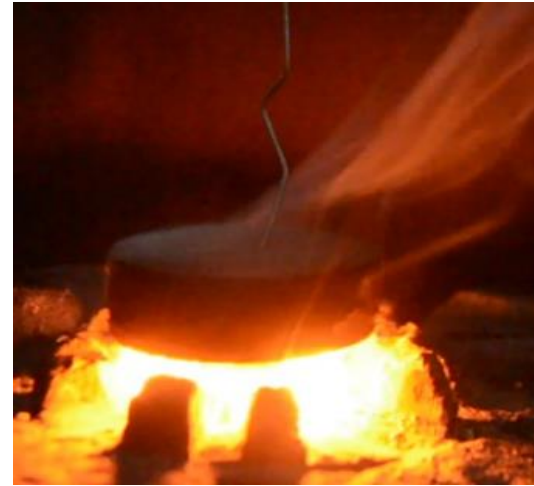

Gambar 3. Proses penyalaan briket

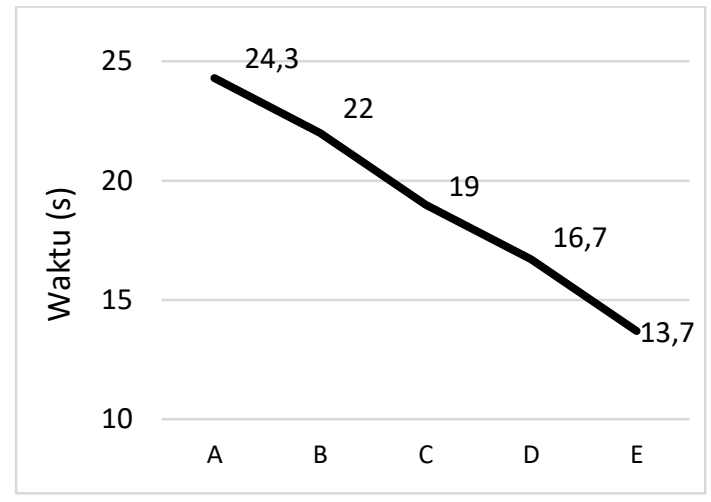

A : cangkang karet $100 \%$

B : kulit kayu gelam 30\% dan cangkang karet $70 \%$

C : kulit kayu gelam 50\% dan cangkang karet $50 \%$

D : kulit kayu gelam $70 \%$ dan cangkang karet $30 \%$

E : kulit kayu gelam $100 \%$

Gambar 4. Grafik lama waktu penyalaan briket

Proses pembakaran briket berlangsung waktu tercepat terjadinya nyala api pada penggunaan kulit kayu gelam $100 \%$ yaitu pada rata-rata waktu 13,7 detik, sedangkan lama waktu terlama briket menyala ada pada cangkang karet $100 \%$, yaitu pada rata-rata waktu 24,3 detik. Semakin banyak campuran kulit kayu gelam maka akan mempersingkat waktu penyalaan briket disebabkan karena dengan penambahan kulit kayu gelam yang berupa serat mempermudah penyalaan awal briket. Tingginya kadar zat-zat terbang (volatile matter) pada kulit kayu gelam juga mengakibatkan briket akan lebih mudah terbakar.

2. Lama waktu proses pembakaran briket Pada proses pembakaran briket dari variasi campuran kulit kayu gelam dan 
cangkang karet lama waktu diperlukan untuk membakar keseluruhan massa briket, dapat dilihat pada gambar 6 .

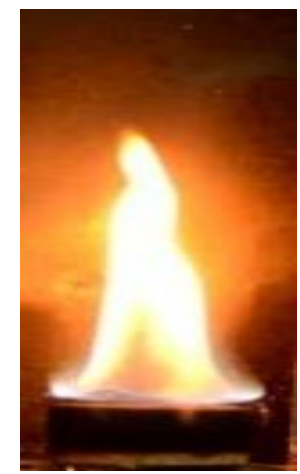

Gambar 5. Nyala api pembakaran brikett

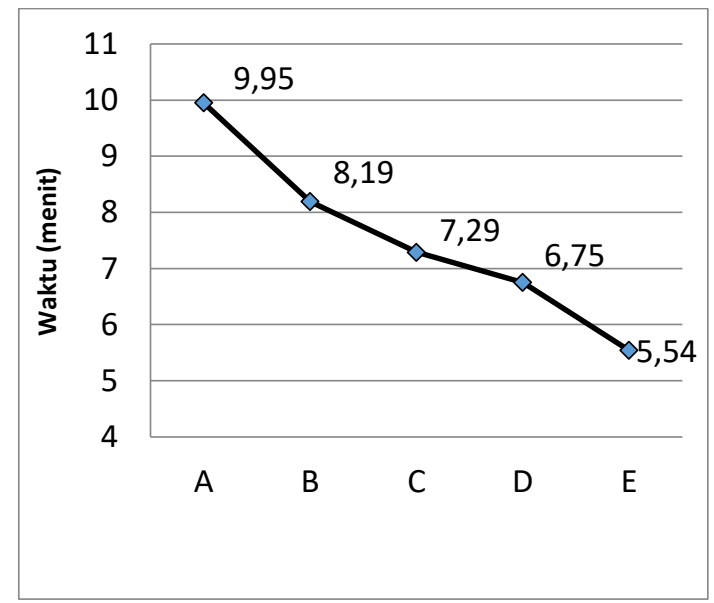

A : cangkang karet $100 \%$

B : kulit kayu gelam 30\% dan cangkang karet $70 \%$

C : kulit kayu gelam 50\% dan cangkang karet $50 \%$

D : kulit kayu gelam $70 \%$ dan cangkang karet $30 \%$

E : kulit kayu gelam $100 \%$

Gambar 6. Grafik lama waktu proses pembakaran pada briket

Lama waktu proses pembakaran briket yang paling tinggi ada pada cangkang karet $100 \%$ yaitu selama 9.95 detik, sedangkan lama waktu proses pembakaran briket yang paling rendah atau singkat ada pada kulit kayu gelam 100\% yaitu selama 5.54 detik. Lama waktu proses pembakaran briket meningkat seiring bertambahnya persentasi cangkang karet pada briket, hal ini disebabkan tekstur cangkang karet yang lebih keras dan padat adanya kandungan lignin sehingga pada proses pembakaran memerlukan waktu lama untuk penguapan briket dan terjadinya api pembakaran untuk membakaran seluruh bagian briket.

3. Massa akhir briket hingga menjadi abu

Briket yang telah mengalami proses pembakaran sampai menjadi abu di timbang, untuk mengetahui terjadinya perubahan massa akhir pada proses pembakaran briket dari variasi campuran kulit kayu gelam dan cangkang karet.
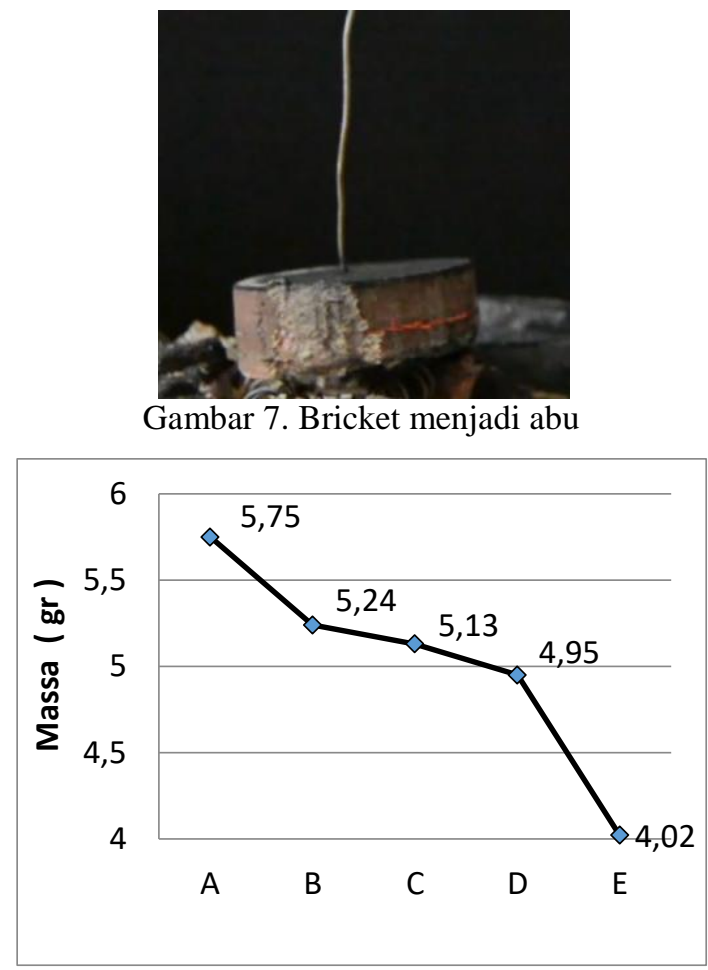

A : cangkang karet $100 \%$

B : kulit kayu gelam $30 \%$ dan cangkang karet $70 \%$

C : kulit kayu gelam 50\% dan cangkang karet $50 \%$

D : kulit kayu gelam $70 \%$ dan cangkang karet $30 \%$

E : kulit kayu gelam $100 \%$

Gambar 8. Grafik perubahan massa briket hingga menjadi abu

Pada gambar 8 menjelaskan grafik pengaruh hubungan antara persentase campuran kulit kayu gelam dan cangkang karet terhadap perubahan massa briket hingga menjadi abu. Massa briket terendah ada pada kulit kayu gelam $100 \%$ yaitu 4,02 gr dan massa briket tertinggi ada pada cangkang karet $100 \%$ yaitu 5,75 gr. 
Massa akhir briket mengalami penurunan seiring bertambahnya persentase campuran kulit kayu gelam pada briket. Perubahan massa pada setiap variasi campuran briket pada proses pembakaran hingga menjadi abu dapat dijelaskan bahawa setelah briket kulit kayu gelam dan cangkang karet terbakar maka bahan bakar semakin berkurang kerena terbetuk gas dari seluruh material sehingga terjadi penyalaan besar selanjutnya material bahan telah habis dan menjadi abu dari sisa pembakaran. Selain itu cangkang karet memiliki kadar abu yang lebih besar dibandingkan kulit gelam.

\section{Kesimpulan}

Lama waktu mulai penyalaan bertambahnya persentase campuran kulit kayu gelam. Semakin besar persentase campuran cangkang karet pada briket, maka waktu proses pembakaran semakin lama. Massa akhir briket mengalami penurunan seiring bertambahnya persentase campuran kulit kayu gelam pada briket.

\section{Referensi}

[1] Fauzi, Iif R., et al. 2016. Kelayakan Pengembangan Perkebunan Karet di Kabupaten Tanah Bumbu Kalimantan Selatan.Indonesian Journal of Natural Rubber Research, vol. 34, no. 1, 2016, pp. 107-118.

[2] Susila, I. W., 2015. Pemanfaatan Bungkil dan Kulit Biji Karet Sebagai

Bahan Bakar Alternatif Biobriket

Dengan Perekat Tetes Tebu. Jurusan

Teknik Mesin,Fakultas

Teknik,Universitas Negeri Surabaya.

[3] Mariki, I Wayan Wawan. 2017. Karakteristik pembakaran Biobriket Kulit dan Cangkang Karet dengan Perekat Glyserin. Jurnal Rekayasa Mesin Vol.8, No.1

[4] Malakauseya, Jeffrie Jacobis. 2013. Pengaruh Prosentase Campuran Briket Limbah Serbuk Kayu
Gergajian dan Limbah Daun Kayu putih Terhadap Nilai Kalor dan Kecepatan Pembakaran. Universitas Brawijaya. Malang.

[5] Ratnawati. 2016. Pemanfaatan Limbah Kayu Galam (Melalueca spp) dan Limbah Tempurung Kelapa (Cocos nucifera L.) sebagai Bahan Baku Pembuatan Briket Arang dengan Komposisi yang Berbeda (Karya Ilmiah). Politeknik Pertanian Negeri Samarinda, Samarinda, Indonesia.

[6] Wardana, ING. 2008. Bahan Bakar dan Teknologi Pembakaran. PT. Danar Wijaya Brawijaya University Press, Malang 